\title{
Not a Stitch out of Place: Assessing Students' Attitudes Towards Multimodal Composition
}

\author{
Jeanne Law Bohannon \\ Kennesaw State University, Georgia, USA
}

Article received 11May 2015, accepted 25 May 2015, final version 7 June 2015

DOI: http://dx.doi.org/10.5565/rev/jtl3.631

\begin{abstract}
This article traces a brief history of multimodal composition practices in the field of writing studies. It frames writing instruction through the theoretical lens of democratic pedagogy and presents the works of key composition scholars. The author then describes a mixed methods research study, conducted with first-year students on the STEM campus of a state comprehensive university. Students participated in a survey that asked their attitudes towards multimodal writing assignments, digital literacies, and learning outcomes. The author draws conclusions about the effectiveness of multimodal composition based on students' responses and provides supplemental information on the types of assignments and examples of student work.
\end{abstract}

Keywords: multimodal composition, qualitative research, digital writing, composition history, new media

\section{Resumen}

En este artículo se describe, brevemente, la historia de las prácticas de composición multimodal en el campo de los estudios de la escritura. Enmarca la instrucción de escritura a través de la perspectiva teórica de la pedagogía democrática y presenta las obras claves sobre la didáctica de la escritura. Luego, el autor describe un estudio de investigación basada en los métodos mixtos, realizado con estudiantes en su primer año de estudios en una universidad estatal, enfocado a los STEM (las Ciencias, la Tecnología, la Ingeniería y las Matemáticas) en los Estados Unidos. Los estudiantes participaron en una encuesta sobre sus actitudes hacia las tareas de escritura multimodales, las alfabetizaciones digitales, y los resultados de aprendizaje. El autor llega a conclusiones acerca de la efectividad de la composición multimodal basado en las respuestas de los estudiantes y proporciona información adicional sobre los tipos de tareas y ejemplos de trabajos para los alumnos.

Palabras clave: La escritura multimodal, la investigación cualitativa, la escritura digital, la historia de la composición, los nuevos medios de comunicación

\section{Resum}

En aquest article es descriu, breument, la història de les pràctiques de composició multimodal en el camp dels estudis de l'escriptura. Emmarca la instrucció d'escriptura a través de la perspectiva teòrica de la pedagogia democràtica i presenta les obres claus sobre la didàctica de l'escriptura. Després, l'autor descriu un estudi d'investigació basada en los mètodes mixtos, realitzat amb estudiants en el seu primer any d'estudis en una universitat estatal, enfocat als STEM (les Ciències, la Tecnologia, l'Enginyeria i les Matemàtiques) als Estats Units. Els estudiants van participar en una enquesta sobre les seves actituds cap a les tasques d'escriptura multimodals, les alfabetitzacions digitals, i els resultats d'aprenentatge. L'autor arriba a conclusions sobre l'efectivitat de la composició multimodal basat en les 
respostes dels estudiants i proporciona informació addicional sobre els tipus de tasques i exemples de treballs per als alumnes.

Paraules clau: L'escriptura multimodal, la investigació qualitativa, l'escriptura digital, la història de la composició, els nous mitjans de comunicació

\section{Introduction}

"English Composition. Each candidate will be required to write a short English composition, correct in spelling, punctuation, grammar, and expression, the subject to be taken from such works of standard authors." - Harvard Catalogue 1873-1874

"Expos 10. Emphasizes analytical writing: reading closely and analyzing texts; using evidence; questioning and engaging with sources; developing ideas and structuring arguments; and communicating those ideas to readers in clear, effective prose." - Harvard Catalogue 2010-2011

Whether prescriptive like the $19^{\text {th }}$ century or process-driven like the $20^{\text {th }}$ century, institutions of higher education have placed strong focus on rhetorical composing in the course descriptions and outcomes for first-year composition courses. The theoretical differences are evident, but the rhetorical behaviors that demonstrate textual competency are still similar. Beginning also with compulsory courses in the 19th century, the patchwork tapestry of composition in higher education has been always-already crafted out of scraps and treasures, old and new fibers. Its multi-textural surface reflects and refracts lights off thousands of shimmering threads. When we look closer, patterns and images emerge, ones that are specific and meaningful to each of us separately and all together at once.

As scholars trace the history of writing studies in concert with others who seek to transform it, we weave a tapestry of diverse epistemologies and practices that define who we are as compositionists and writing instructors. Although we teach textual process across undergraduate and graduate curricula, engaging first year writers in authentic academic conversations is a key aspirational goal of compositionists, because first-year courses are a focal point for developing writing and building student-scholars. Given that we are a discipline in motion and a field in flux, we mostly acknowledge our openness to new methods and our willingness to seek out viable new discourse spaces within which we provide similar spaces for our students. I am interested in gaining insight as to how institutions can re/mix first year writing spaces to focus on student engagement and increase undergraduate writing competency. I believe that our best window of opportunity to accomplish this mission begins in first-year writing 
programs. First-year writing courses are spaces of opportunity because they are required courses across disciplines and majors. The project that follows comes from such a space and rests on the voices of student writers who are entering academic conversations.

As a compositionist and a practitioner of multimodal writing myself, I would like to advocate that we all take a long look at our pedagogical methodologies. We need to examine how we view first-year writing courses, the student-scholars who populate them, and the instructors who teach them. I suggest further that we should perform qualitative/quantitative research queries that ask students to interrogate the spaces in which they write and examine the methods that reach them in their multiplicity of meaning-making, discourse communities. I believe that too often we have found ourselves as an "Other" within Academe, due to these defining characteristics and our "stitch out of place" positions that frequently contradict historical constructs within higher learning and even in our own pedagogical frameworks.

Based on student responses to multimodal assignments and learning outcomes, I advocate for composition instructors to integrate multimodal writing opportunities into their courses that encourage students to stretch their rhetorical abilities and challenge them as emerging scholars to think critically about their writing and speaking, not just in their academic discourse but also in their multiple discourse communities. Dialogic, multimodal learning creates situated, specific discourse opportunities for student-scholars to enter into academic conversations and affect change, using their own rhetorical voices.

The mixed-methods case study I have conducted and will describe in this article examines how students perceive multimodal writing in terms of learning outcomes and how they feel about integrating multiliteracies and multimodalities into their writing courses. Such research will benefit students and practitioners in our field, add to our field's knowledge constructs, and perhaps affect change in the ways universities value first year composition courses and the student-scholars enrolled in them.

\section{What is Multimodal/Digital/Multiliteracies Composition Practice?}

In 2004, more than ten years ago, the Conference on College Composition and Communication (CCCC) produced a position statement on its website on what multimodal and its associated synonyms mean to learning and meaningful text production. Part of the statement reads: 
Creating images, sounds, designs, videos, and other extra-alphanumeric texts is an esthetic, self originated, self-sponsored activity for many writers. Digital technologies have increasing capacity for individuals to adapt the tools for their own information and communication purposes. Students have the capability to apply literacy skills to real world problems and knowledge-building. They are able to exercise creativity, work for social justice, and pursue personal passions.

While acknowledging that the text itself is a bit outdated in some ways, we can nevertheless see a burgeoning genre of composition receive recognition and validation by a national governing group. In terms of validating multimodal practice in a composition classroom, the key words in the CCCC position statement are "self-sponsored...adapt tools...apply literacy...knowledgebuilding." When we parse out the statement, what we have is a theoretical endorsement for practicing multimodal composition.

Yet, even before the CCCC statement, a group of scholars from the United States, United Kingdom, and Australia came together to discuss and theorize the future or writing instruction, assessment, and text production. What came out of that month of meetings in 1996 is what we know now as the theory of multi-literacies. The New London Group, as they are referenced as a whole, envisioned new ways for students to demonstrate writing competency, including composing with visual images, audio recordings, and new technologies. The group argued in their seminal article, A Pedagogy of Multiliteracies, that "literacy pedagogy must now account for the burgeoning variety of text forms associated with information and multimedia technologies" (p. 60). So, students can produce meaningful discourse in other ways than the written word. Instructors of composition can assess these texts as networked writing connections - to both students' lives and the multiple discourse communities in which they practice. Opening up such diverse, and often public, discursive spaces in our classrooms gives students the chance to "be" writers and gives us the chance to "see" them as such.

\section{Making the Case for Dialogic Multimodal Instruction}

In 1997, Ken Bruffee further challenged writing instructors to view student writing as a situated negotiation AND a Conversation. He argued that, writing is "internalized social talk made public and social again" and that it was "a conversation of mankind." (p. 400). That same year rhetoric 
scholar Patricia Bizzell called for "open areas" of discursive space to challenge and break the binary of author/non-author (1997, p. 376). Four years later, feminist composition scholar Susan Jarratt (2000) wrote in College English about the joy of shared authority and writing across genres and disciplines "between the lines" (p. 390). What these giants of composition were saying builds on the New London Group, specifically that writing is a social endeavor, that we must view students as writers, and that students can demonstrate their writing prowess by producing texts across genres and fields of inquiry.

Writing in the Handbook of Reading Literacy, educational scholar Don Leu argues that technology will change the pace, form, and function of literacy and that, digital technologies are rapidly and continuously redefining the nature of literacy (2000). He further discusses how quickly classrooms will become irrelevant if instructors cannot keep up with students as they explore digital technologies and their associated writing spaces. Leu hits on the fact that we have come to embody almost twenty years later: we must provide students with opportunities for writing that embrace the Digital.

Fast-forward to 2001, the year in which Marc Prensky coined the terms "digital native" and "digital immigrant." Writing in his text On the Horizon, Prensky opined about a new generation of learners, one that our dated educational systems and pedagogies were not ready to teach. This new generation of digital natives required its instructors to meet students in the spaces the students themselves occupied, namely digital spaces. Scholars in the field(s) of composition have since theorized and practiced what we do once we reach out to students and assess their work in digital spaces.

New Media scholar Cheryl Ball, in a 2006 Convergence article, theorizes how instructors respond to multimodal writing from a combined design and rhetoric perspective. She lauds that writing teachers have always, when embracing new theories such as new media, approached them from what they know and what they do not know and have learned to reconcile those connections and differences to find a more useful theory. (Ball, 2006, p. 410)

Compositionists have that reputation, don't we? We are able to weave our way through genres of writing, embracing the new and re/stitching the old.

In her 2009 CCC article, Grobman calls for first year writing instructors to participate in a new education movement -developing well-informed, undergraduate writers through open 
classroom dialogue and democratic teaching practices. Grobman asserts that undergraduate research is "a potentially democratic learning site in which students write themselves into disciplinary conversations and challenge faculty/scholar-constructed representations of them" ( $p$. 177). Since so much empirical research in our field is based on student writing, I would further add that we too often set up a faculty-student binary, in which student writers are viewed as the opposite of authors and instead are considered "error-makers, plagiarists, (non) authors, and academic outsiders" (Ibid., p. 178). This binary can also be viewed as one in which the teacher represents authority and the student represents a novice. While I understand that students come to us with diverse levels of writing prowess, I believe that, as instructors, we can and should disrupt this binary, facilitating authentic writing development for and with students.

Grobman admonishes instructors for "not articulating to our students the methodology of inquiry in our field except as injunctions to 'write a paper'." She cautions that while "we may not always agree on a process of inquiry... we need to articulate our methodology, design appropriate tasks for students, and ask for authentic scholarship." Grobman opines, and I agree, that the field of English Studies is moving towards opening up academic conversations to undergraduates. Measuring student attitudes towards multimodal learning outcomes creates a space that engenders authentic writing and encourages student-scholars to produce work through re/mixed lenses in these democratic spaces.

In a 2009 interview with the literacy magazine Hot Metal Bridge, New Media scholar Anne Wysocki theorizes about academic digital writing:

[Textobjects] we make that circulate among others show back to us our embedded belonging in the humanatural world, show us our abilities to participate, show us how our senses are always entwined with there being sensible stuff, show us how our senses exist because there is sensible stuff. (Forlow, 2009, para. 15)

For Wysocki, digital writing is social writing. It connects us with a wider digital audience, but it also connects us as a classroom of students working collaboratively to produce non-linguistic or post-linguistic texts. In an earlier 2004 essay, "Opening New Media to Writing: Openings and Justifications," Wysocki challenges us as instructors of writing to ask our students to experience agency through identities and produce texts in multimodal ways. What does this mean? Student writers need to be proficient in observing an immediate experience, recording it succinctly, organizing it rhetorically, and presenting it in a creative, digital way. 


\section{Making the Case that Students Want Multimodal Assignments}

A key element of developing effective multimodal writing opportunities and making a case for multimodal learning outcomes is listening to students' voices. Writing in a recent issue of College English about a 2005 longitudinal study, Lunsford, Fishman and Liew (2013) describe (college) student writers as fearful...not necessarily of plagiarism (although this was a concern of a small group), but of their work not having "value." Results like this came in during a longitudinal study of student writing at Stanford: it is "important for students to identify their writing as valuable, something they might care about, and others might want to borrow, share, cite, or even steal." (Ibid., p. 476). The data collected by Lunsford and her team further support the idea that students need to write in genres that provide meaning to the student-writers themselves. One way to engender this type of meaningful composition is to provide students with public, multimodal writing assignments that are crowd-sourced and student-driven, decreasing the chance of plagiarism and increasing authentic writing. When we work with digitalities as multimodal composition practice, we also produce opportunities for student-scholars to negotiate their own rhetorical growth and take ownership of associated outcomes. So, when students compose rhetorically in these spaces, such as blogs, wikis, and podcasts, they "write" their own negotiated meanings for a public audience and see that their public "texts" have value outside of a classroom setting. Because multimodal writing is inherently diverse in process and presentation, it engenders students to compose openly, because they need not worry about the traditional pitfalls of sharing information or plagiarizing.

In Writing Together (2011), Lisa Ede and Andrea Lunsford discuss the participatory process of multimodal writing in terms of how it "provides opportunities for writerly agency, even as it challenges notions of intellectual property" (p. 241). Their argument makes me think about multimodal and digital pieces as more than just assignments. Opportunities for diverse acts of composition, often taking the form of Wikis and YouTube videos, create, nurture, and produce communities of writers as much as they produce living products that can serve audiences outside of our university walls. Digital writing spaces provide a basecamp for these types of composition projects that can grow over time, through iterations and editions based on feedback from audiences and users -- students. The mixed methods research that I present here provided me with extensive data regarding how students either embrace or reject multimodal writing, as it is 
conducted in a theoretical framework informed by twenty years of scholarship from scholars both in the field of composition and others related to it. In performing the pedagogy that led to the survey and in conducting the survey itself, this project is looking back to informing sources and practicing forward to new possibilities.

\section{Methodology}

What does multimodal writing look like in a first-year writing course? First, we need to delineate what the modalities are and how they connect to each other. Figure 1 illustrates my version of the New London Group's modalities.

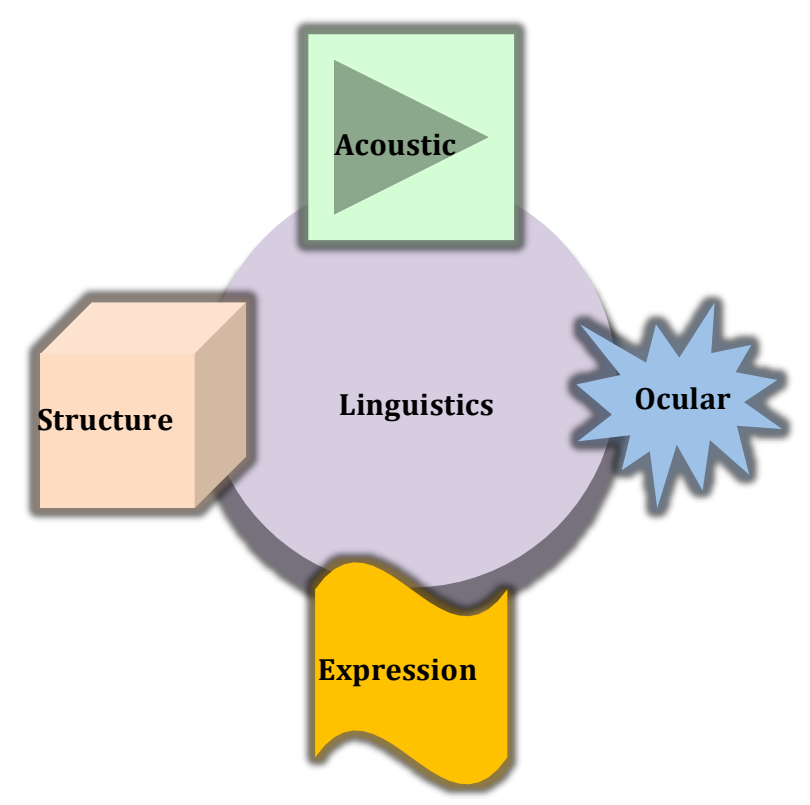

Figure 1. Bohannon's Version of Multimodal Elements from New London Group

Rhetorical communication happens when writers combine linguistic, acoustics, ocular, structural, and expressive elements. Linguistics are the alphanumeric symbols that describe both an individual's intrinsic process when creating language, as well as the extrinsic considerations like context and culture. Think of linguistics as the center of communication. It is the anchor for written words. Acoustics are considerations of sound including volume, the rhetorical amount of sound effects, music, and other aural elements.

Ocular considerations are those parts of a text in which the author must choose the most rhetorical appeal to the eye. So, this element has much to do with first impressions, what the text 
looks like. In a standard "dear teacher" essay, authors consider this element with font, charts, photographs, diagrams, etc. When we design a digital text we have to consider further issues such color, lighting, and text-objects.

The structure of a piece of communication is how authors put it together for a specific audience. Structure includes spatial and arrangement components. It is how authors design communication.

The expression put into a text includes non-verbal cues or physical gestures. For instance, when recording a vlog, authors make appropriate choices in how they physically move as part of the video presentation. It is important that authors have a working knowledge of how expression informs the rhetorical choices they make in textual communication. Taken together, multimodalities inform rhetorical considerations for authors in regards to non-traditional, digital texts.

\section{Multimodal Assignment Context}

Multimodal assignments in a first-year writing classroom take many forms. I have included examples of assignments for further reading. ${ }^{1}$ A foundational assignment for the group of students surveyed for this project was a re/mix. We started with an annotated bibliography, with each student choosing her/his subject based on chosen major or interest in a field of inquiry ${ }^{2}$. Because students chose their own research topics, they were not plagued with issues of sharing information. They could collaborate and work freely together, because their research and texts were individualized. After completing the annotated bibliography and revising from feedback, students then wrote and produced vlog-casts of their research. Working together, but each with an individual vlog-episode, students wrote outlines and transcripts first. After researching vlog production techniques, students then re/mixed their annotated bibliographies into multimodal pieces. ${ }^{3}$ For the final part of the assignment, students uploaded their vlogs to Youtube and distributed links to them to their coursemates for electronic feedback.

The class produced other multimodal assignments during the semester, including Prezi (interactive presentation platform) research presentations and electronic research proposals. The idea of multimodalities of writing in a first-year composition classroom can be as simple as producing a Prezi or as involved as crafting a vlog. From an instructor's perspective, the key to 
making multimodal assignments work for students is providing clear, measurable learning outcomes that are associated with these assignments.

\section{Learning Outcomes}

As instructor of record for the writing course described in this research project, I wrote learning outcomes for the course and assignments based on Penney's Bloom's Digital Taxonomy (2015). ${ }^{4}$ For each assignment, I presented and explained the learning outcomes to students, so that everyone knew expectations and parameters for their learning. I asked for students' opinions on these multimodal learning outcomes on the survey I describe here.

\section{Method and Instrument}

The electronic survey that students completed at the end of the writing course consisted of both objective and free response questions, asking students for their opinions on multimodal writing and how this type of writing impacted their learning during the semester. I distributed the survey as a link, with no identifying participant information captured, at the end of the semester - after grades had been posted. The survey contained six overarching questions about students' experiences with learning, with Likert scale ratings as subsections for one question. ${ }^{5}$

\section{Participant Demographics}

Students who participated in the survey were enrolled in an 1102 Honors composition course on the engineering and science-focused campus of a large comprehensive state university. The students represented a cross-section of STEM majors, including various engineering fields, computer science, mathematics, and video game development. They represented a section of high-achieving students, who, by their high school grades and SAT scores, participated in the Honors Program at the University. They embodied traditional university student demographics in terms of age, with an average age of 18. They further represented normalized student characteristics in regards to their expectations of a first-year writing course. Since they were all STEM majors, students considered English 1102 to be a requirement that would be easily met, "a box ticked off," as one student put it. The class was populated with 15 students, with 14 students identifying as male and one student identifying as female. The gender composition of the class aligns with that of the STEM campus of the University. All students enrolled in the course who 
participated in the survey met Marc Prensky's 2001 definition of "digital natives," students who were born after 1980 and who have always had the digital technologies such as the Internet as known presences in their lives.

\section{Discussion and Analysis}

The results of the survey come from 15 student responses, making this project a case study. While small in number, the case study itself is representative of common traits of first-year writing courses, thus data gathered from the study can be generalized and replicated in a larger setting.

When students were asked to respond on a five-point Likert scale rated from Strongly Agree to Strongly Disagree, with a neutral answer between agree and disagree, regarding their attitudes towards multimodal writing, their answers were both expected and surprising. When asked about their general attitudes towards electronic submission of assignments, which is a multimodality itself, more than three-quarters $(80 \%)$ of students replied that they preferred to submit their work electronically in a writing course. One student caveated a response: "submitting work [electronically] in a writing course is fine, however in other courses, such as those with labs or lots of math, I prefer hard copies." Roughly the same number of students agreed that they liked to submit their work in our University's learning management system (Desire 2 Learn, Pearson). Getting specific answers from students about a university's LMS is an important data set, because it allows instructors to customize LMS selections and seek out other options.

The survey also asked students to rate their experiences with specific, multimodal assignments. Students were asked about their writing experiences with Prezi. When asked about presenting their work with Prezi, students responded with mixed results. What is interesting in this response is that $27 \%$ of students still prefer PowerPoint to Prezi when presenting their written work. This finding is surprising, given that Prezi is a free, Cloud-based presentation platform, that gives authors many design options and interactive capability and also because STEM students tend to prefer innovative technology applications. One would surmise that digital natives would prefer much more to use a tool that meets their needs for technological potential. Although a majority prefer Prezi to PowerPoint after using Prezi (60\%), 27\% of students still 
prefer PowerPoint, with $13 \%$ undecided. So, almost half of the digital natives surveyed did not have a positive perception of Prezi as opposed to PowerPoint. To counter this number a bit, I found that $80 \%$ of respondents strongly agreed or agreed that Prezi was an interesting way to present their work. The remaining $20 \%$ had no opinion. We can conclude here that, while students like aspects of Prezi as a presentation tool, they still prefer to work with PowerPoint, even if doing so makes their presentations less interesting to their audience. Complementing these answers, I found that 93\% of students surveyed thought that Prezi helped them better organize their thoughts in presenting their final research proposals for the class, with the remaining 7\% indicating no opinion. This number is significant, because students agree that Prezi helps them better organize, yet they still prefer another program. Their preferences indicate that they may perform their multimodal writing, in this particular instance, more authentically if consideration is given to seeking student voices for presentation platform preference. Students' answers gave me something to think about as I revise the multimodalities of assignments for future courses.

The survey also asked students to give their estimations on the Vlog-cast assignment. Students' responses indicated a more positive view of the impact of vlog-casting. All students agreed that the vlogcast assignment met the same learning outcomes as a traditional essay, and 93\% thought the vlog-cast assignment was more interesting than a "Dear Teacher" essay. Further, $87 \%$ of surveyed students reported that the vlog-cast assignment made them interrogate their writing practices. One student responded to an open feedback question that, "the vlog-cast assignment helped me realize that writing comes in all different forms." Overall, students seemed pleased with the assignment itself as well as their process in performing it. Their responses should inform any necessary course revision.

In addition to querying students about their attitudes towards e-submission and specific assignments, I also wanted to know whether or not they perceived a growth in their writing from the beginning to end of the semester, given the context of multimodal compositions in the course. The answers I gathered indicated a commonality of experiences regarding students' views on multimodal writing in a first-year writing course. Table 1 shows the trends of three overarching statements categorized by the number of students who responded to each.

Bellaterra Journal of Teaching \& Learning Language \& Literature. 8.2 (May-June 2015) ISSN 2013-6196 
Table 1. Responses to Overarching Learning Survey Statements

\begin{tabular}{|c|c|c|c|c|}
\hline Statement & Strongly Agree & Agree & No Opinion & $\begin{array}{l}\text { Total Strongly } \\
\text { Agree/Agree } \%\end{array}$ \\
\hline $\begin{array}{l}\text { I learned more by } \\
\text { doing multimodal } \\
\text { writing than print } \\
\text { writing. }\end{array}$ & 11 & 3 & 1 & $93 \%$ \\
\hline $\begin{array}{l}\text { I will use the skills } \\
\text { I learned about } \\
\text { multimodal writing } \\
\text { in my future } \\
\text { courses. }\end{array}$ & 9 & 5 & 1 & $93 \%$ \\
\hline $\begin{array}{l}\text { I increased my } \\
\text { digital literacy this } \\
\text { semester. }\end{array}$ & 10 & 4 & 1 & $93 \%$ \\
\hline
\end{tabular}

Students overwhelmingly and consistently reported that they performed better and grew as writers by composing multimodal texts during the semester. With the exception of one participant, who had no opinion, students indicated that they increased their digital literacy by composing in digital spaces. That number translates to $93 \%$ of students across all three statements. This number is significant because it shows that students view multimodal writing as an important skill set to have and see digital literacy as directly influenced by performing multimodal writing assignments. For instructors, these answers give credence to twenty years of theory on multimodalities and writing studies. Respondents in this case study were, however, a limited number. They represented a cross-section of high-achieving students enrolled on the STEM campus of a large, comprehensive state university. Although mixed methods case studies may not indicate larger trends, I believe that this study can and should be replicated to include more student voices in the design and planning of multimodal assignments in first-year writing courses.

\section{Final Thoughts}

Many writing instructors have embraced multitudinal incarnations of multimodal writing, since it was first theorized in the 1990s. The field of writing studies continues to expand its use of multimodal assignments as we move to meet the needs and learning styles of new generations of students, who increasingly locate themselves in digital spaces for both playing and learning. Moreover, one of the vital items teacher-scholars often miss when developing these types of 
assignments is seeking out students' attitudes towards types and use of multimodalities. Too often we get caught up in the design of assignments as we, the experts, envision them; we consider learning outcomes, assessment, and resources. However, we also need to consider how our students will respond to these assignments and how they will meet the associated learning outcomes that will enable them to grow their rhetorical prowess. As instructors and designers, our ultimate goal is to facilitate our students' rhetorical growth and to diversify their writing prowess. If we are to accomplish this goal, we must work with our students, taking their voices into account. We must design our assignments together, crowd-sourcing them with the class, and assessing their effectiveness, based on feedback from our students.

Qualitative and quantitative data are important components in drawing conclusions from students' learning experiences. Interpreting data gleaned from student surveys will complete a bigger picture of national trends in the methods of teaching writing. I encourage other writing instructors to use the survey (edit as needed) and report their own results on my blog, www.rhetoricmatters.org. My objective with this case study is to use it as a departure point for larger conversations on multimodal writing and how students, who are digital natives or digital immigrants, feel about performing multimodal compositions either in conjunction with or as a replacement for traditional print essays.

\section{References}

Ball, C. (2006). Designerly = readerly: Re-assessing multimodal and new media rubrics for use in writing studies. Convergence: The International Journal of Research into New Media Technologies, 12(3), 393-412. http://dx.doi.org/10.1177/1354856506068366

Bizzell, P. (1997). Cognition, convention, and certainty: What we need to know about writing. In V. Villanueva (Ed.) Cross-talk in comp theory (pp. 365-389). Urbana: National Council of Teachers of English.

Bruffee, K. (1997). Collaborative learning and the "conversation of mankind." In V. Villanueva (Ed.) Cross-talk in comp theory (pp. 393-414). Urbana: National Council of Teachers of English.

Conference on College Composition and Communication. (2004). CCCC position statement on teaching, learning, and assessing writing in digital environments. Retrieved 5 June 2015 from: http://www.ncte.org/cccc/resources/positions/digitalenvironments

Ede, L., \& Lunsford, A. (2011). Writing together. Boston: Bedford St. Martins.

Forlow, R. (2009). Interview: Composition and the digital: Anne Frances Wysocki on making, teaching, text. Retrieved 5 June 2015 from http://hotmetalbridge.org/archivelinks/issue5/composition-and-the-digital-anne-frances-wysocki-on-making-teaching-text/ 
Grobman, L. (2006) The student scholar: (Re) negotiating authorship and authority. CCC 61(1), 175- 96.

Jarratt, S. (2000) Comment: Rhetoric \& feminism: Together again." College English 62, 390-393.

Leu, D. (2000). Literacy and technology: Deictic consequences for literacy education in an information age. In R. Barr, M. Kamil, P. Mosenthal, \& D. Pearson (Eds.) Handbook of reading research (pp. 743-770). New York: Routledge.

Lunsford, A., Fishman, J., \& Liew, W. (2013). College writing, identification, and the production of intellectual property: Voices from the Stanford study of writing." College English, (75)5, 470-492.

New London Group. (1996). A pedagogy of multiliteracies: Designing social futures. Harvard Educational Review, (66)1, 60-92. http://dx.doi.org/10.17763/haer.66.1.17370n67v22j160u

Prensky, M. (2001). Digital natives, digital immigrants. On the Horizon, (9)5, 1-6. http://dx.doi.org/10.1108/10748120110424816

Wysocki, A. (2004). Opening new media to writing: openings and justifications. In A.F. Wysocki, J. Johnson-Eilola, C. L. Selfe, \& G. Sirc (Eds.) Writing new media: Theory and applications for expanding the teaching of composition (pp. 1-23). Boulder, CO: Utah State University Press.

\footnotetext{
${ }^{1}$ Theory behind and public domain examples of multimodal assignments may be found at http://rhetoricmatters.org/integrating-social-media-into-your-pedagogy/

${ }^{2}$ For the assignment sheet, outcomes, and examples of the annotated bibliography, visit http://rhetoricmatters.org/uncategorized/annotated-bibliography/

${ }^{3}$ Assignment sheets, outcomes, and examples may be found at : http://rhetoricmatters.org/game-analysis-vlogcast/ http://rhetoricmatters.org/game-analysis-vlogcast/ Analysis Vlog-cast

${ }^{4}$ The revised Pyramid of Digital Blooms, with examples of digital applications, may be found at http://faculty.indstate.edu/spenney/bdt.htm

${ }^{5}$ Link to Survey: First-Year Multimodal Writing Survey Described in this Article
}

\section{Author information:}

Jeanne Law Bohannon is an assistant professor of English in the Digital Writing \& Media Arts department of Kennesaw State University. She currently teaches research methods, functional grammar, and digital rhetoric in both graduate and undergraduate programs. Her research interests include recovering feminist historical rhetorics and measuring student attitudes towards multimodal composing.

Email: jbohan12@kennesaw.edu

To cite this article:

Bohannon, J.L. (2015). Not a stitch out of place: Assessing students' attitudes towards multimodal composition. Bellaterra Journal of Teaching \& Learning Language \& Literature, 8(2), 33-47. DOI:http://dx.doi.org/10.5565/rev/jtl3.631 